\title{
Creating a Space for Peace-making: Burundi and Beyond
}

\author{
Tim Wichert
}

\begin{abstract}
Mennonites and Quakers have historically renounced the use of violence for resolving conflicts. From 1994 to 1997 the Mennonite Central Committee (MCC) ran a program of civilian peacemaking in Burundi at the request of local Quakers. Their goals were modest, hoping that international volunteers could assist in reducing the level of violence and creating space for positive things to happen. Lessons learned were discussed at a seminar hosted by the Quaker United Nations Office in Geneva in May 1997.
\end{abstract}

\section{Précis}

Historiquement, les Mennonites et les Quakers ont abandonné le recours à la violence dans la résolution des conflits. Entre 1994 et 1997 le Comité Central Mennonite a piloté un programme de pacification civile au Burundi à la demande des Quakers locaux. Leurs objectifs étaient modestes et se fondaient sur l'espoir que des volontaires internationaux pourrait contribuer à une réduction du niveau de violence et à la constitution d'un espace permettant la réalisation d'actions positives. Les leçons tirées de cette expérience furent discutées lors d'un Séminaire tenu par le Bureau Quaker des Nations Unies à Genève en mai 1997.

In late 1994 Burundi Quakers invited the Mennonite Central Committee (MCC) to send international volunteers to Burundi. What is the role of international agencies in such a setting of conflict?

Tim Wichert is currently with the Mennonite Central Committee's UN Liaison Office in New York. From 1994 to 1997 he worked with the Quaker UN Office in Geneva, and prior to that was with MCC in Nairobi, Kenya. He has a law degree from Queen's University, Kingston, Ontario and has practised refugee law in Toronto.
Amongst other things, the MCC facilitated unarmed outside interventions, encouraged dialogue amongst church leaders, planned regional training in conflict resolution, developed nonviolence materials in Kirundi, and organized trauma healing workshops.

The program coordinators were responsible for supervising volunteers who came for six month periods to be a peace presence amongst threatened communities. The volunteers were not chosen for their particular skills or training; their mere presence was considered more important than their activities. They received no special training. Most were in their twenties. Most lived in rural locations with Burundian people (usually Hutu) and with access to a vehicle. There were few administrative and backup structures.

In May 1997, the Quaker Office in Geneva organized a workshop to discuss the MCC program in Burundi with UN agencies and Non-Governmental Organizations. The following issues were highlighted:

\section{Objectives}

- To reduce the level of violence (i.e., perhaps by "shaming") through the presence of individuals.

- To encourage dialogue and understanding at the grassroots level, by bringing people together for specific activities.

- To "create space" for something positive to happen.

- To accompany individuals who felt vulnerable so they could carry on with their own activities

There was no attempt to create a buffer zone between communities and to monitor or document human rights violations.

\section{Ambiguities/Dilemmas}

- Should those in conflict be brought together, or should they be kept apart?
- It is difficult, if not impossible, to both "stand with" people and document human rights violations;

- What should bedone with evidence of human rights violations?

- Should those intervening maintain a low or a high profile?

\section{Positive Impacts of Presence}

The presence of individuals:

- facilitated meetings with authorities, e.g. visits to jails, getting through checkpoints;

- established communication with military personnel at local level, building trust;

- promoted inter-ethnic dialogue, e.g. through conflict resolution seminars;

- established an inter-ethnic peace committee in one local community;

- initiated volleyball games between Tutsi soldiers and Hutu civilians; and

- helped to share Burundi experiences with the outside world.

\section{Negative Impacts of Presence}

- Some people were seen as benefiting more and resentment arose.

- Some regarded the volunteers with suspicion, especially those without a specific activity/job (there was one nurse); rumours arose that they were mercenaries.

- Their presence attracted criminal elements, assuming they had material goods.

- Their presence and association with Burundians could lead to greater threats or targeting after they left the country.

- They were helping the most vulnerable but were never confronting the belligerents.

- Their presence gave vulnerable people the confidence to take risks they perhaps should not have.

- Their presence perpetuated stereotypes, namely that the lives of out- 
siders were more valuable than those of local people.

- Some people resented their presence, thinking that Burundi problems should be solved by Burundians ("Leave Burundi for Burundians").

\section{Limitations}

- Insecurity increased, especially against expatriates.

- Expatriates increasingly attracted negative attention.

- The Burundian Quaker Church was unable to provide continued support, and some Burundian Quakers had to flee the country.

- The MCC was perceived as proHutu, because most volunteers worked or lived with Hutus.

- Grassroots work could notbe really effective when the problem was at a national, political level.

- Timing-what might be appropriate at one point may not be at another.

- UN missions are limited by their inability to obtain clearance from UN and local authorities to move about the country because of security concerns-this affects the extensiveness of their work.

\section{What Could be Done Differently}

- More planning is required regarding goals, strategies, and training.

- Necessary administrative structures must be in place, with requisite financial resources.

- Those participating need emotional support; there is no such thing as a "low maintenance" person.

- Maintain a creative balance between short and long term involvement-6 months might be insufficient but the tension of the situation and burnout are very real problems.

- More balanced presence with both Hutus and Tutsis is required.

- Try to have Burundian Tutsi and Hutu advisors for such a program.

\section{Other Lessons (Open Discussion)}

Outsiders need to be aware of the work at different "levels":
- There is a need to work with local people and build on local capacity; a willingness to "suffer with" and to be more closely linked to local structures.

- Many small, local initiatives lack support, e.g. peace-making manuals, training, finances.

- There could be more in-country, inter-agency dialogue on peacemaking (not simply on humanitarian issues and relief).

- There could be more support for the International Tribunals, aimed at creating a climate of justice.

- There must be political pressures and dialogue at national, regional and international level.

Outsiders must:

- have experience, maturity and sincerity (local language skills also important, e.g. Kirundi);

- have modest objectives, and be modest about what can be done;

- build trust, while being aware of extensive mistrust.

Further,

- impartiality is important for building trust, but is difficult to achieve in practice; and

- there will always be ambiguities and dilemmas; it is important to remain aware of these.

\section{Who Should Do Peace-making Work}

- Leave Burundi for Burundians? No, there is a role for outsiders within certain parameters.

- Civilian peace-making interventions cost much less than military peace-making (e.g., Blue Helmets).

- Should UN agencies have a peacemaking mandate; should it be "mainstreamed" within their programming? (e.g., staff training in conflict transformation, programs for conflict transformation and peace education)

- Can UN agencies do peace-making work through "humanitarian observers" or "White Helmets"?

- Should peace-making be done primarily by organizations which specialize in this (e.g., NGOs)?

\section{Richi Riporis}

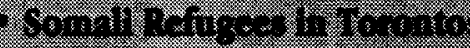

4.50010

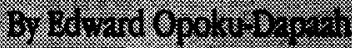

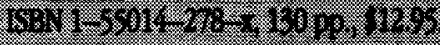

This is the hist compteherste stoth of

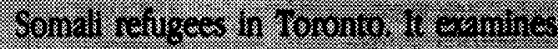

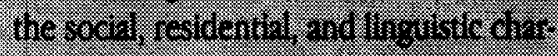

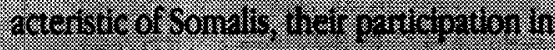

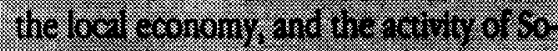

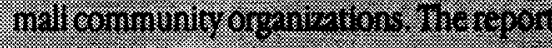

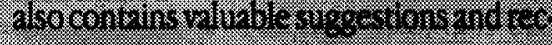
ommendations concening vuluble and norederidentserice delivery to this con numity:

- 0 .

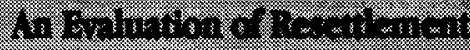
and 4 ingeris

By anet Maldhin

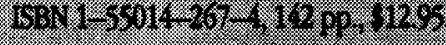

This majorstudy of Cambodihn refugees in Onarib eamines the cirects of rarious fomsorsponsonshy on ambolinnest tement. If aso focises ond the linguistic

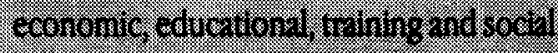
dimensions of the whole protess of ad dy?

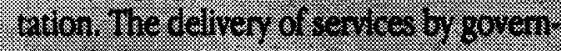
mental and KCO agencies 25 vell as the

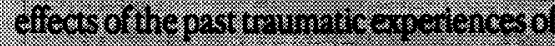
genoctre and mas serrition on combo

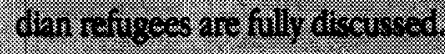

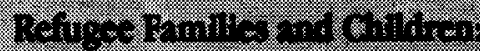

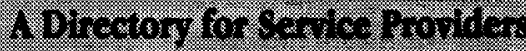

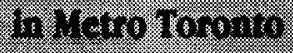

uampied bo

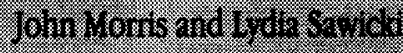

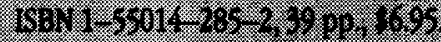

This directory is destogred for service pro

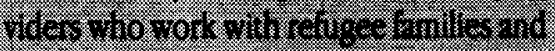

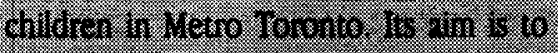

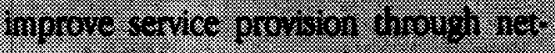

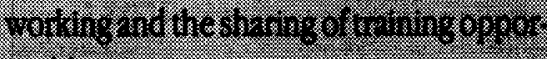
anives.

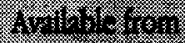

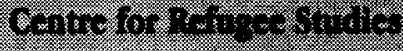

